\title{
Natural iodine in a clay formation: Implications for iodine fate in geological disposals
}

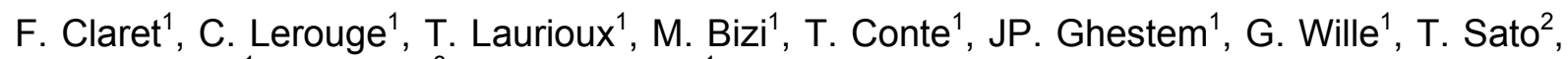 \\ E.C. Gaucher ${ }^{1}$, E. Giffaut ${ }^{3}$, C. Tournassat ${ }^{1}$
}

\begin{abstract}
${ }^{1}$ BRGM, 3 Avenue Claude Guillemin, 45060 Orleans Cedex 2, France
${ }^{2}$ Laboratory of Environmental Geology, Research Group of Geoenvironmental/Engineering Division of Solid Waste, Resources and Geoenvironmental/Engineering Graduate School of Engineering, Hokkaido University Kita 13 Nishi 8, Sapporo 060-8628, Japan

${ }^{3}$ Andra, 1 rue Jean-Monnet, Chatenay-Malabry, 92298, France.
\end{abstract}

Corresponding author: f.claret@brgm.fr

To be submitted to Geochimica Acta

\section{Abstract}

lodine is one of the most problematic radioisotopes in the context of nuclear waste geological disposal due to its high mobility. Considerable effort has been dedicated to the measurement of its potential retardation during diffusive transport leading to conflicting results, from no retardation to significant retardation, leading in turn to considerable debate. The present study aims at providing new insights into this aspect of the iodine problem by careful quantification of iodine reservoirs in the Callovian-Oxfordian (COx) clay rock taken here as model material for these studies. The present study confirmed the ubiquitous presence of iodine at $1-5 \mathrm{mg} \mathrm{kg}^{-1}$ level in the COx clayey formation. The iodide concentration level in the porewater is also confirmed at a value in the range $\sim 20-40 \mu \mathrm{mol} \mathrm{L}^{-1}$, i.e. higher than the expected range of radio-iodine concentration in the far-field of the storage. Surprisingly, most of the iodine was found not to be associated with organic matter but rather in an inorganic form associated with carbonate minerals. This result has potentially significant implications for the fate of radio-iodine. In undisturbed far-field conditions, most natural iodine would not be accessible for isotopic exchange with radioactive iodine, reducing the effective $\mathrm{Kd}$ to negligible values. During laboratory experiments, good monitoring of the geochemical parameters (at least the $\mathrm{Eh}, \mathrm{pH}, \mathrm{P}_{\mathrm{CO} 2}$, [Ca] and [Mg]) is mandatory to avoid iodine-bearing carbonate precipitation and to enable rigorous interpretation of the iodide diffusion/retention experiments. 


\section{INTRODUCTION}

Underground nuclear waste disposal in clayey formations is under investigation in Western Europe. Among long life elements, only ${ }^{129} \mathrm{I},{ }^{36} \mathrm{Cl}$ and ${ }^{79} \mathrm{Se}$ are able to migrate significantly from such a repository (Altmann, 2008). Due to its mobility, its long half-life period (approximately 16 million years) and its ubiquity in radioactive waste, iodine ${ }^{129}$ I will make a significant contribution to potential overall long-term dose resulting from the waste storage (Altmann, 2008; Grambow, 2008). ${ }^{129}$ I has a complex chemistry in the environment. lodine can be found in an elemental form $\mathrm{I}_{2}$ (valence 0 ), as iodide $\mathrm{I}^{-}(-1)$ or iodate $\mathrm{IO}_{3}^{-}(+5)$. Its fate and transport are dictated by its chemical speciation (Koch-Steindl and Prohl, 2001). In the following, when the redox state cannot be specified, the notation iodine* will be used. Soluble iodine* will probably exhibit its -1 valence state as the iodide anion $\left(\mathrm{I}^{-}\right)$in clayey formations such as Callovian-Oxfordian (COx, France), Opalinus Clay (OPA, Switzerland) or Boom Clay (Belgium), according to the near-neutral $\mathrm{pH}$ and low redox potential of these media (Pearson and Waber, 2001; Pearson et al., 2003; Gaucher et al., 2006; Appelo et al., 2008; Vinsot et al., 2008; Gaucher et al., accepted). Due to the inherent negative surface charge of clay rock minerals at near neutral and basic $\mathrm{pH}$ conditions, $\mathrm{I}^{-}$is repelled from their surface and most show an absence or even a negative adsorption (e.g. carbonates, quartz, chlorite, montmorillonite and muscovite, see Tournassat et al. 2007 and references therein). With regards to sorption behaviour on whole clay rock samples, there is however widespread controversy with regard to the presence or not of I' sorption (e.g. see (Bazer-Bachi et al., 2006; Tournassat et al., 2007). This controversy is linked (i) to the very low measured distribution coefficient $(\mathrm{Kd})$ values, the uncertainty of which can be higher than the value itself, and (ii) to the potential mechanism(s) of I' sorption, if they exist. In order to avoid the first problematic point on Kd error bands, numerous studies have been devoted to the acquisition of the $\mathrm{I}^{-}$retardation factor in transport experiments (through-diffusion, outdiffusion, column experiments, (Van Loon et al., 2003; Descostes et al., 2008) where error bands are very low compared to batch sorption experiments (Bazer-Bachi et al., 2006). Until recently, these transport experiments conducted on different clay formation samples have systematically shown a low but significant retardation factor for iodide transport in comparison to the $\mathrm{Cl}^{-}$conservative tracer, thereby confirming a priori the effectiveness of a retention mechanism.

With regards to the second point, it is noticeable that these studies did not provide any mechanistic model for the observed $\mathrm{I}^{-}$retention. Based on the observation of $\mathrm{I}^{-}$leaching from COx clay rock samples, Gaucher et al. (2004) and Tournassat et al. (2007) have shown that 
$\mathrm{I}^{-}$is already present in the COx formation at micromolar range concentration. In undisturbed repository far-field conditions, this natural $\mathrm{I}^{-}$solute concentration is expected to be higher than the solute concentration of radioactive $\mathrm{I}^{-}$. If a reversible $\mathrm{I}^{-}$sorption process takes place in the formation, this sorption process would also involve natural iodine* at equilibrium with dissolved $\mathrm{I}^{-}$. As a consequence, the retention of radioactive $\mathrm{I}^{-}$would necessarily involve an isotopic exchange mechanism between natural iodine* from the formation and radioactive $\mathrm{I}^{-}$ leached from the storage. On the other hand, Wittebroodt et al. (2008) have demonstrated through in- and out-diffusion transport experiments on Tournemire argillite that in conditions where isotopic exchange is minimized (by using $\mathrm{I}^{-}$concentrations higher than the natural $\mathrm{I}^{-}$ content of the clay), retention of $\mathrm{I}^{-}$still occurs. Their experiments do not invalidate the isotopic exchange process as being an unavoidable process at trace $\mathrm{I}^{-}$concentration but highlight the necessary occurrence of, at least, one additional retention process that should not be representative of a far-field process in undisturbed conditions. This could be due for instance to a non-saturation of $\mathrm{I}^{-}$sorption sites with natural iodine* ${ }^{*}$, or a coprecipitation process.

Recent experiments by Glaus et al. (2008) have made it possible to obtain a clearer view of what could happen during diffusion experiments. By careful preparation of their tracer solution using anion chromatography columns, these authors showed that I' radiotracers also contain iodate $\left(\mathrm{IO}_{3}{ }^{-}\right)$. They also showed on OPA samples that $\mathrm{I}^{-}$tracer behaves exactly like $\mathrm{Cl}^{-}$(i.e. no retardation) when $\mathrm{IO}_{3}{ }^{-}$is removed from the tracer solution. $\mathrm{IO}_{3}^{-}$, with high retention processes, exhibited completely different transport behaviour, being in fact rapidly reduced into $\mathrm{I}^{-}$when entering into contact with the solid but also transformed into a non-identified species, probably an organic and/or elemental form of iodine*. Similarly, a minor part of the $\mathrm{I}^{-}$ was also demonstrated to be transformed into an unidentified species during the troughdiffusion experiment time period. These results highlight the fact that iodine* fate in a clay rock exhibiting reducing conditions is highly dependant on (i) the real redox nature of the iodine* tracer (a parameter that is not easily constrained, as demonstrated by these authors), and (ii) the duration and the geometry of the experiment, due to kinetic interactions of the tracer with the clay rock constituents, especially organic matter. By extension, the study by Glaus et al. (2008) also demonstrated that most of the published data showing I' retention in clay rock must be reconsidered as probably being blurred by unexpected and undesired initial experimental conditions. Given the importance of iodine* fate in nuclear waste storage (Altmann, 2008), we anticipate that considerable debate will continue on the existence or not of $\mathrm{I}^{-}$retention and the quantification of its extent.

Apart from this debate, the results of Glaus et al. (2008) also highlight the need to understand natural iodine* behaviour in clay rock systems because radiotracers are 
expected to behave like natural isotopes. The present study aims at providing new insights into this aspect of the iodine* problem by careful quantification of iodine* reservoirs in the Callovian-Oxfordian clay rock taken here as model material for these studies. 


\section{MATERIAL AND METHODS}

\subsection{ORIGIN OF CLAY ROCK SAMPLES}

Thirty three Callovian-Oxfordian clayey samples from the ANDRA (French Radioactive Waste Management Agency) Underground Research Laboratory (Meuse/Haute Marne, France) were investigated for iodine*. The samples originated from twelve boreholes crosscutting the clayey formation (Figure 1): EST 205 (one sample), EST211 (nine samples), EST212 (12 samples), EST 312 (one sample), EST322 (two samples), EST413 (one sample), EST423 (two samples), PAC1002 (one sample), PAC1011 (one sample), PAC 2001 (one sample), PPA 91 (one sample) and FOR1118 (one sample).

The selection of samples from a $30 \mathrm{~km}^{2}$ area in different boreholes and at different levels of the boreholes can be considered as representative of the clayey formation. The mineralogical log of the boreholes EST 211 and EST212 and the location of the samples of this study referring to these two boreholes are given in Figure 2. The mineralogy and the geochemistry were intensively studied in the framework of the ANDRA research program dedicated to deep geological disposal of radioactive waste (Andra, 2005). As presented in Figure 2, the claystones consist of a clay fraction, a quartz-dominant silted fraction (with minor feldspars) and carbonates (calcite and dolomites) with minor pyrite and celestite. The top of the formation is richer in limestone layers. The lower and the middle parts of the clay formation are clay-rich with maximum clay content and a change of clay mineralogy corresponding to the maximum of the flooding surface (Claret et al., 2004; Gaucher et al., 2004). The carbonate fraction is composed of detrital aragonite and calcite derived from benthic and pelagic fauna, and diagenetic carbonates (calcite, dolomite/ankerite). Organic matter contents range between 0.5 and $1.3 \mathrm{wt} . \%$ (Disnar et al., 1996; Landais and Elie, 1999; Gaucher et al., 2004; Claret et al., 2005; Hautevelle et al., 2007; Deniau et al., 2008). The geochemistry of organic matter demonstrated both its terrestrial and marine origins, a marine influence being dominant in the lower part of the clayey formation (Disnar et al., 1996; Landais and Elie, 1999; Hautevelle et al., 2007). Combined mineralogical, fluid inclusion and organic matter studies have shown that the maximum burial temperatures attained in the clayey formation did not exceed $40-50^{\circ} \mathrm{C}$ (Pellenard et al., 1999; Elie et al., 2000).

The selected samples originated from boreholes of successive core drilling campaigns, using different conditioning procedures, as discussed in Gaucher et al. (2004). Some of the 
selected samples were more than eight years old and were stored in aluminium-plastic bags under an $\mathrm{N}_{2}$ atmosphere. Given the storage time, the inner atmosphere of the aluminiumplastic bags has probably been replaced by an air atmosphere leading to some oxidation of the samples (De Craen et al., 2004). These old samples were used only for total iodine* measurements and to determine water extractable iodine*.

\subsection{SAMPLE PREPARATION}

The samples were first roughly powdered in an agate mortar by hand, and then in a grinder. This was done in the absence of oxygen, using a $\mathrm{N}_{2}$ filled glove box, in order to prevent oxidation of redox sensitive materials such as, for example, pyrite and organic matter.

Size separation of different fractions was performed on a freshly $\mathrm{N}_{2}$ drilled sample taken in a gallery of the ANDRA underground research laboratory (sample EST26479), hereafter named reference sample, using sieving and liquid elutriation. All the size separation steps

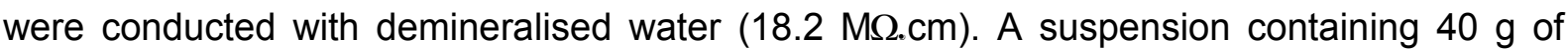
rocks per litre was first passed through 4 different sieves $(20,32,40$ and $100 \mu \mathrm{m})$ and then elutriated until $3.5 \mu \mathrm{m}$ with 4 conical elutriators having a section of $12.5,25,50$ and $100 \mathrm{~cm}^{2}$. A centrifugation step was also performed in order to collect the fraction below $1 \mu \mathrm{m}$ starting from the fraction below $3.5 \mu \mathrm{m}$. Nine different size fractions were extracted (Table 1). During sieving and elutriation, no dispersive additives were used in order to preserve the chemistry of the mineral phases contained in the starting material. This might induce artefacts in the particle classification (e.g. fine particles coming with larger particles). On the other hand, the average diameter measured for each fraction by laser diffractometry (Malvern Mastersizer S) with a Mie optical is in fairly good agreement with the sieving and elutriation results (data not shown). The iodine* content in these fractions was determined by Radiochemical Neutron Activation Analysis (RNAA) by the Josef Stefan Institute.

\subsection{ANALYTICAL TECHNIQUES}

\subsubsection{Total iodine* concentration determination}

A large panel of measurement techniques for iodine* concentration in soils, sediments and rocks are available in the literature. Some studies have shown that methods based on acid digestion can lead to wide variations in the recovery of iodine* (Jones et al., 1979; Sun and Julshamn, 1987; Wifladt et al., 1989). Other methods based on alkaline ashing (Marchetti et 
al., 1994) or sample oxidation (Moran et al., 1995) exist, but most often the extraction yield is linked to the sample itself. Incidentally, it is difficult to be sure that a method optimized for biological samples can be successfully applied to sediments. One of the most reliable techniques to extract halogens from geological samples is the technique based on pyrohydrolysis (Michel and Villemant, 2003). The rock powder is mixed with the same amount of accelerator $\left(\mathrm{V}_{2} \mathrm{O}_{5}\right)$ in a platinum crucible or a quartz boat at $\sim 1200^{\circ} \mathrm{C}$ through a vapour stream (wet oxygen flow). The stream is cooled down to $-25^{\circ} \mathrm{C}$ in a condensing column and collected in $10 \mathrm{~mL}$ diluted $\mathrm{NaOH}$ or $\mathrm{Na}_{2} \mathrm{CO}_{3}$ solution. Still based on the principle of sample vaporization, ( $\mathrm{Li}$ et al., 2002) developed the so called "sintering" method. The sample is mixed with flux (sodium carbonate and zinc oxide), sintered at $650^{\circ} \mathrm{C}$ for 40 minutes in a muffle furnace and then dissolved in hot water. However, these vaporization techniques are not easy to perform in the laboratory and the use of a large amount of flux, cation-exchange resin and matrix separation step leads to a high procedural blank, with a consequent deterioration in the detection limit (Michel and Villemant, 2003; Bing et al., 2004). Recently, Bing et al. (2004) have developed a simple method. lodine* is extracted in screw top PTFE-lined stainless steel bombs using a $10 \% \mathrm{v} / \mathrm{v}$ ammonia solution at $185^{\circ} \mathrm{C}$. According to the author, this method is suitable for determination of iodine* in soil, sediment and biological samples. Given the apparent disagreement of results when using different techniques, we decided to apply and compare four different techniques in order to obtain the total iodine* concentration: overnight extraction by nitric acid digestion at $90^{\circ} \mathrm{C}$ in closed PFA (perfluoroalkoxy) vessels or ammonia method (Bing et al., 2004) followed by Inductively Coupled Plasma Mass Spectrometry (ICP-MS) measurements, and two neutron activation techniques.

The ICP-MS analysis was performed on a THERMO X Series II instrument at mass 127. In order to stabilize the signal and minimize memory effect, samples as well as standard solutions used for calibration contained $0.25 \% \mathrm{TMAH}$ (tetramethyl ammonium hydroxide) (Muramatsu and Wedepohl, 1998; Tagami and Uchida, 2005)

RNAA was performed by the Josez Stefan Institute in Slovenia (Dermelj et al., 1990; Osterc and Stibilj, 2005; Osterc et al., 2007). $180 \mathrm{mg}$ of rock powder was pelletized with $120 \mathrm{mg}$ of cellulose powder. The pellet was then heat-sealed in an acid-cleaned polyethylene ampoule and irradiated simultaneously with an appropriate aliquot of working standard solution (100 $\mathrm{mg}$ of $10 \mu \mathrm{g} \mathrm{I} \mathrm{g}{ }^{-1}$ in $5 \%$ solution of $\mathrm{NH}_{3}$ ) also sealed in a polyethylene ampoule, for approximately 2-3 minutes in a rabbit in the pneumatic system of the Joseph Stefan TRIGA Mark II reactor at a neutron fluence of $3.5 \times 10^{12} \mathrm{n} \cdot \mathrm{cm}^{-2} \cdot \mathrm{s}^{-1}$. The irradiated sample and $90-100$ $\mathrm{mg}$ of iodine* carrier (solution of $\mathrm{KI}$ in $\mathrm{NH}_{3} ; 50 \mathrm{mg} \mathrm{I} \mathrm{g}^{-1}$ in $5 \%$ solution of $\mathrm{NH}_{3}$ ) were then 
combusted in an oxygen atmosphere ( $4 \mathrm{~L}$ Schöninger flask) containing a reducing acid solution. lodine* was extracted with chloroform via the classical redox reaction with $\mathrm{NaNO}_{2}$ (See Osterc and Stibilj (2005) for the detailed procedure). Stripping of the organic phase to purify iodine* followed, which was then re-extracted with chloroform and transferred to a vial for gamma-ray measurement of the induced radionuclide $\left({ }^{127} \mathrm{I}(\mathrm{n}, \gamma)^{128} \mathrm{I}, \sigma_{\mathrm{th}}=6.2 \mathrm{~b}, \mathrm{t}_{1 / 2}=25\right.$ $\min , \mathrm{E} \gamma=442.9 \mathrm{keV}$ ). After this latter measurement, the organic phase was quantitatively transferred to a flask for spectrophotometric chemical yield determination of iodine* at 517 $\mathrm{nm}$.

Instrumental Neutron Activation Analysis (INAA) was performed by the Pierre Sue Institute. The sample was subjected to INAA in the Osiris Reactor at Saclay in France. A cadmiumlined irradiation position in the reactor was used to attenuate the $\mathrm{Na} \mathrm{Cl} \mathrm{Mn}$ signal that will interfere with ${ }^{128}$ (Ozaki and Ebihara, 2007). Monitors of Au and Al were used. After two minutes irradiation and a delay of approximately one hour, the activity of ${ }^{128}$ I was recorded by gamma spectrometry using the 443-keV lines over 20 minutes. After another 6 hours delay, another 1 hour counting was made. The iodine* concentration was determined using the $\mathrm{k}_{0}$ method (De Corte and Simonits, 2003).

\subsubsection{Sequential extractions}

As proposed by Tournassat et al. (2007), iodine* in the COx could be mainly associated with organic matter. In order to check this hypothesis and to see if mineral phases could also contribute to the natural iodine* stock within the COx, a sequential chemical extraction was used. This latter is inspired by Tessier (1979). Even if this protocol was developed for cation, Hou et al. (2003) have shown that it is possible to apply it to iodine ${ }^{*}$ chemical fractionation in Chernobyl soil.

The extraction was carried out as follows:

Water soluble fraction: $20 \mathrm{~mL}$ of water was added to $4 \mathrm{~g}$ or $8 \mathrm{~g}$ of crushed rocks and the suspension was shaken for $24 \mathrm{~h}$ at room temperature. The leachate was separated by centrifugation and the residue 1 was subjected to the second extraction step.

Exchangeable fraction: $20 \mathrm{~mL}$ of $1.0 \mathrm{~mol} \mathrm{~L}-1$ ammonium acetate $\left(\mathrm{NH}_{4} \mathrm{OAc}\right)$ was added to the residue 1 and the suspension was shaken for $3 \mathrm{~h}$. Again the leachate was separated by centrifugation and the residue 2 was subjected to the third extraction step. 
Carbonate fraction: $20 \mathrm{~mL}$ ( $30 \mathrm{~mL}$ in the case of samples with $8 \mathrm{~g}$ in the first step) of an acetate/acetic acid buffer ( $\mathrm{pH}$ 5.0) was added overnight to residue 2. Again the leachate was separated by centrifugation and the residue 3 was subjected to the fourth extraction step.

Organic matter fraction: $20 \mathrm{~mL}$ ( $30 \mathrm{~mL}$ in the case of samples with $8 \mathrm{~g}$ in the first step) of $30 \% \mathrm{H}_{2} \mathrm{O}_{2}-\mathrm{HNO}_{3}(\mathrm{pH} 2.0)$ was added to residue 3 for $5 \mathrm{~h}$ at $50^{\circ} \mathrm{C}$. The leachate was separated by centrifugation.

The iodine* content for each extraction step $n\left([I]_{n}\right.$ in $\left.\mathrm{mg} / \mathrm{kg}\right)$ was calculated as follows:

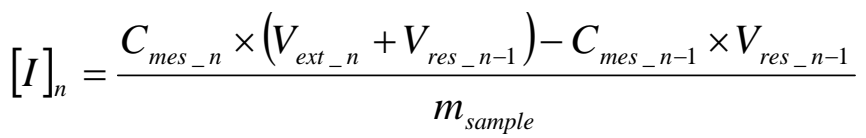

Equation 1

Where $\mathrm{C}_{\text {mes_n }}$ is the iodine ${ }^{*}$ concentration $(\mathrm{mg} / \mathrm{L})$ in solution measured at the step $n, V_{\text {ext_n }}(\mathrm{L})$ the volume of extractant used at the $\operatorname{step} n, \mathrm{~V}_{\text {res } n-1}(L)$ the residual volume remaining in the centrifuge tube after the previous step, and $m_{\text {sample }}(\mathrm{kg})$ the initial mass of solid used for the extraction.

It should be noted that in comparison to the classical protocol (Tessier et al., 1979; Quevauviller, 1998), the extraction step corresponding to the metal oxides fraction was not carried out. This is due to the fact that there is no simple iron (hydr)oxide in the COx (Gaucher et al., 2004; Tournassat et al., 2008). Concerning the organic matter fraction, a second step using 3.2 mol L-1 $\mathrm{NH}_{4} \mathrm{OAc}-20 \% \mathrm{HNO}_{3}$ for $1 \mathrm{~h}$ was not carried out because this step is used to avoid resorption of cations on the solid matrix, but in our case, iodine* would be present as a neutral or anionic species.

This protocol was firstly developed and applied to the reference sample under exposed air conditions. A slightly modified protocol was used, again under air, in order to check for any possible correlation between iodine* and organic matter release. Sodium chloride $(1 \mathrm{M} \mathrm{NaCl})$ and hydrochloric acid $(2 \mathrm{M} \mathrm{HCl})$ were used, instead of $\mathrm{NH}_{4} \mathrm{OAc}$ and the acetic/acetate buffer in order to measure the dissolved organic carbon (DOC) in solution. Sodium citrate $(1 \mathrm{M})$, sodium bromide (1 $\mathrm{M} \mathrm{NaBr}$ ) and sodium fluoride (1 $\mathrm{M} \mathrm{NaF}$ ) were also used as alternative reagents to check the counter anion dependency of exchangeable iodine* in the second step of the extraction procedure.

lodine* is a redox sensitive element and the extraction protocol was therefore also performed under inert $\mathrm{N}_{2}$ atmosphere conditions in a glove box for the reference sample. In addition, total iodine* content was measured under the same conditions on 27 additional samples from different locations and depths to gain a picture on the iodine* variability in the COx formation. 


\subsubsection{EPMA for iodine* analysis in the solid}

Electron Probe Micro-Analyser (EPMA) analyses of carbonates and organic matter were performed on polished thin sections using a Cameca SX50 electron microprobe with a $20 \mathrm{kV}$ acceleration voltage, a current beam of $50 \mathrm{nA}$ and a 1-2 $\mu \mathrm{m}$ beam width. $\mathrm{Ca}, \mathrm{Fe}, \mathrm{Mg}, \mathrm{S}, \mathrm{Sr}$, $\mathrm{Si}$ and $\mathrm{P}$ elements were analysed simultaneously with iodine* ${ }^{*}$ to determine the microphases associated with organic matter and the nature of carbonates. Ca-La, S-Ka and I-La, $\beta$ were analysed using a PET crystal. Fe-Ka was analysed using a LiF crystal. Mg-Ka, Si-Ka, Sr-Ka and P-Ka were analysed using a TAP crystal. Counting times were $40 \mathrm{~s}$ for $\mathrm{Ca}, \mathrm{S}, \mathrm{Fe}, \mathrm{Mg}$, $\mathrm{Sr}, \mathrm{P}$ and $\mathrm{Si}$ and $240 \mathrm{~s}$ for I. Corrections were made for counter dead time, atomic number effects, fluorescence and absorption using a ZAF computing program (Sweatman and Long, 1969).

EPMA analysis of iodine* was difficult due to evidence of interference between the most commonly used I L $\alpha$ X-ray emission line and a satellite peak associated with the $K \beta$ line of Ca (Figure 3). Analyses of iodine*-free apatite standard (39 wt.\% Ca) provided evidence of a high interference of $1030 \pm 90 \mathrm{mg} \mathrm{kg}^{-1}$. For this reason, iodine ${ }^{*}$ was measured on the I-La Xray line in Ca-free phases and I-L $\beta$ X-ray line in Ca-rich phases and micro-environments. The counting time of $240 \mathrm{~s}$ was determined to minimize the detection limit at $140-150 \mathrm{mg} \mathrm{kg}^{-1}$ in organic matter and at $120-130 \mathrm{mg} \mathrm{kg}^{-1}$ in carbonates, according to the calculation of the detection limit by statistical approach of Ancey et al. (1977b; 1977a).

\section{RESULTS AND DISCUSSION}

\subsection{TOTAL IODINE* CONTENT MEASUREMENT METHODS}

It is clearly apparent from Table 2 that the different extraction procedures do not lead to the same result. With the COx reference sample, acid digestion is more efficient (a tenfold order of magnitude higher) than ammoniac digestion. This difference cannot be explained by experimental problems such as leakage, because measurements performed on a reference sample designated GBW07311 (a Chinese stream sediment) and certified by the Institute of Geophysical and Geochemical Exploration (China) led to the same value with both extraction procedures. In comparison to acid digestion, the value obtained by RNAA was $77 \%$ higher. The value given by INAA was in the average range between acid digestion and RNAA results. This discrepancy between INAA and RNAA could either be explained by the fact that the INAA measurement was performed on another batch or by a lower sensitivity than RNAA (Ebihara et al., 1997). 
This preliminary test made it possible to show that the ammonia alkali digestion method proposed by Bing et al. (2004) is not adapted to clay rock samples, although it gives valuable results for the certified standard. Differences in iodine* environment (type of organic matter or mineral) between the certified standard and the clay rock sample are certainly responsible for the observed discrepancy. Given that $\mathrm{HNO}_{3}$ extraction gives better results, part of the iodine* is likely to be associated with a mineral or organic constituent that undergoes degradation upon acid and/or oxidative attack. It is worth noting that the certified sample contains almost no calcite, whereas the reference COx sample contains about $14 \%$ calcite/dolomite, suggesting an association of iodine* with carbonate minerals, a point that will be discussed later in this paper.

RNAA is one of the most sensitive analytical methods to measure halogens in trace amounts in geochemical samples (Ebihara et al., 1992; Ebihara et al., 1997; Ozaki and Ebihara, 2007) and yields higher iodine* measurements. Taking into account the possible variability of the iodine* content of the sub-samples used for this comparison of measurement methods, the value obtained with $\mathrm{HNO}_{3}$ digestion remains in an acceptable range. As a consequence and for costs reasons, the $\mathrm{HNO}_{3}$ digestion method was mostly used in the following analyses, while some complementary analyses were performed with RNAA.

\subsection{IODINE* DISTRIBUTION AS A FUNCTION OF SIZE FRACTIONS}

In Table 1, the iodine* concentration measured by RNAA is given for different size fractions. The values obtained for total organic carbon (TOC) and carbonate are also reported. A good correlation is found between iodine* concentration and carbonate content (Figure 4). Note that the carbonate content was not measured for the fraction below $7 \mu \mathrm{m}$. However, the smaller the fraction the higher the clay content and carbonate therefore represents a minor contribution. This correlation provides additional evidence of the association of part of the iodine* with the carbonate mineral fraction. It is nevertheless impossible to state from these measurements if the correlation is direct (iodine* incorporated in the mineral matrix) or indirect (e.g. iodine* association with the organic matter bound to carbonates). Surprisingly, an anti-correlation between iodine* concentration and TOC is evidenced, although organic matter is usually thought to be the main reservoir for iodine* accumulation (Tournassat et al., 2007). Considering the iodine*/carbonate correlation, this finding is nevertheless logical since organic matter is preferentially associated with clay mineral surfaces, i.e. the fine fraction of the sample (e.g. Claret et al., 2004; Schafer et al., 2009). 


\subsection{SPATIAL VARIABILITY OF IODINE* CONTENT IN THE COX FORMATION}

Total iodine* contents were measured on 28 different samples using the $\mathrm{HNO}_{3}$ extraction procedure in order to gain information on COx formation heterogeneities. Total iodine* content lies typically in the range $1-3 \mathrm{mg} \mathrm{kg}^{-1}$. Theses values are comparable to those given by Fuge and Johnson (1986) for carbonates and shales. Two higher values (4.4 and $5.1 \mathrm{mg}$ $\mathrm{kg}^{-1}$ ) were measured on the top of the formation. It is worth noting that these latter values were obtained for samples with a higher carbonate content (more than 50\%, Figure 5). In some cases, but not systemically, the trend observed for carbonate is quite well correlated with total iodine* content, thus confirming the observation shown on a single reference sample in Figure 4.

\subsection{IODINE* DISTRIBUTION IN PORE WATER, MINERALS AND ORGANIC MATTER}

\subsubsection{Chemical sequential extraction}

The results of the chemical sequential extractions performed on the reference sample are given in Table 3. There is a general agreement between the oxic and anoxic extractions.

From the water soluble extract, it is possible to derive the iodide concentration in the porewater $\left(C_{\text {pore }}\right)$ :

$C_{\text {pore }}=\frac{1000 \times[I]_{1}}{128.9 \times w_{a}}\left(\mu \mathrm{mol} \mathrm{L}{ }^{-1}\right)$

Equation 2

where $w_{a}$ is the water content accessible to anion $\left(\mathrm{L} \mathrm{g}^{-1}\right)$. This calculation is based on the assumption that only iodide originally contained in the porewater volume was extracted. Half of the total water content of the clay samples ( $4 \%$ in gravimetric scale) was considered in the calculation in agreement with a mean estimate of the anion accessible porosity (Pearson, 1999; Gaucher et al., 2006). According to Gaucher et al. (2004) the water content ranges between 6 and $9 \%$ in the clay rich horizons of the COx. A value of $8 \%$ was chosen in agreement with a mean value calculated from the database from Lerouge et al. (2006).

Using Equation 2, the derived $\mathrm{I}^{-1}$ concentration in pore water is between 24 and $38 \mu \mathrm{mol} \mathrm{L}^{-1}$. This is in agreement with the value estimated by Appelo et al. (2008) from in situ diffusion experiments $\left(35 \mu \mathrm{mol} \mathrm{L} \mathrm{L}^{-1}\right)$ or measured in situ $(20 \mu \mathrm{mol} / \mathrm{L})$ by Vinsot et al. (2008). The exchangeable fraction was always below the measurement uncertainty, independently of the extracting agent used (sodium fluoride, bromide and citrate). 
The main reservoir for iodine* is the carbonate fraction, in agreement with the findings obtained on size fractions of the reference sample (Figure 4) and on iodine* distribution at the formation scale (Figure 5). This finding is potentially in conflict with the usual assumption that iodine* is mainly associated with the organic matter of rock or sediment (Schlegel et al. 2006, Tournassat et al. 2007). However, such a preferred iodine*/organic matter association is still possible in the studied samples if part of the organic matter is itself entrapped in the carbonate minerals. In order to check the validity of such a hypothesis, the concomitant release of organic matter during the acidic extraction step was measured using $\mathrm{HCl}$ instead of acetic acid/acetate buffer for carbonate dissolution. Extracted iodine* was very similar (Table 3) and the dissolved organic concentration measured in the solution after the $\mathrm{HCl}$ step (25 mg of organic carbon/ $\mathrm{kg}$ of rock, $\mathrm{mg} \mathrm{C}_{\text {org }} \mathrm{kg}^{-1}$ ) was quite low and in agreement with the concentration found by Courdouan et al. (2007), i.e. $12 \mathrm{mg} \mathrm{C}_{\text {org }} \mathrm{kg}^{-1}$. The iodine* / $\mathrm{C}_{\text {org }}$ mass ratio is equal to 0.095 in the reference sample. This value is ten to one hundred times higher than the various values reported by Schlegel et al. (2006) for humic substances, apart from the case of Mobara for which the ratio is comparable. However, in the Mobara area, iodine* has been produced from brines since 1934, with an annual production of 6,000 tons in recent years, which constitutes approximately one third of world iodine* production (Muramatsu et al., 2001). As a consequence, we consider that such high exceptional iodine* content in organic matter is not relevant for the studied COX reference sample. Hence, the high iodine* / $\mathrm{C}_{\text {org }}$ mass ratio found in the COx reference sample provides evidence of the association of iodine* with a mineral matrix other than organic matter, namely carbonate mineral matrix.

The amount of iodine* associated with the organic matter fraction in the fourth extraction step is more erratic. This could be linked to sample heterogeneity but also to the sequential extraction procedure itself. Indeed, some authors have suggested that the $\mathrm{H}_{2} \mathrm{O}_{2}-\mathrm{HNO}_{3}$ mixture step used in the Tessier procedure can lead to loss of iodine* in the leaching process (Hou et al., 2003). This could also explain the lesser extent of iodine* recovery with $\mathrm{HNO}_{3}$ digestion than with RNAA. Nevertheless, it is worth noting that the concentration found in the organic matter is close to that obtained without sequential extraction following the ammonia extraction procedure (cf. Table 2)

In any case, it has been proven here that (i) carbonate minerals are an important if not the main reservoir for iodine* in the COx and (ii) that iodine* is likely to be present in an inorganic form, a result at variance with the usual considered scheme for natural iodine ${ }^{*}$ speciation.

\subsubsection{Electron microprobe analysis}


EPMA was used as a first approach to locate iodine* in the carbonate fraction and in organic matter. Additional measurements were also performed on biophosphates. Organic matter, carbonates and biophosphates were analysed for their iodine* content in five selected samples (see Figure 2). Visible organic matter in the five samples essentially occurred as disseminated brown amorphous particles, black particles (coaly and semi-fusinite, Figure 6) of terrestrial origin and fine-coatings associated with framboids of pyrite and microcrystalline calcite infilling intergranular porosity and secondary porosity due to biological activity (bioturbation, aragonite dissolution). Carbonates were observed as bioclasts (shells and filaments of bivalves, foraminifer tests, brachiopod shells, echinoderm tests) and as cement (micritic calcite, euhedral calcite and dolomite/ankerite, siderite). Biophosphates essentially occurred as undetermined clasts, except in the sample EST5724 in which it may be compared to the teeth section of a pycnodont or crustacean decapod; both have been described in this Jurassic paleo-environment (Dromart et al., 2003; Carpentier et al., 2006). Taking into account the long counting time and the size of the analysed objects, iodine* was measured automatically along micrometric transects of particles, crystals and selected microcrystalline pyrite-OM zones. All of the results are available in the Electronic Annex with a brief description of the different samples.

lodine $^{*}$ is present relatively homogeneously in organic matter associated with pyrite (Figure $7 \mathrm{a}, 7 \mathrm{~b})$ and in marine-derived organic coatings, but not in black particles of continental origin. Rare high values were measured. The origin of organic matter associated with pyrite remains uncertain, but part of these zones is associated with relics of fossils and bioclasts (Figure 7c, $7 \mathrm{~d}, 7 \mathrm{e}$ ) and could be interpreted as relics of soft parts of benthic microfauna. lodine* content values measured in organic matter are generally low. Numerous analyses were not zero but below or quite close to the detection limit, due to the small particle size and high contamination of the matrix. lodine* contents after matrix corrections ranged between 440 up to $3220 \mathrm{mg} \mathrm{kg}^{-1}$. lodine* is differently distributed in carbonates. Numerous analyses were zero, but at least significant values were measured on bioclasts. The highest value was 850 $\mathrm{mg} \mathrm{kg}^{-1}$. A very high value of $1300 \mathrm{mg} \mathrm{kg}^{-1}$ could also be measured in a Sr-Ca carbonate part enclosed in a terebratula shell. No relation was established between values and structures of the bioclasts. The iodine* concentration in carbonate bioclasts and partly degraded organic matter are consistent with studies of iodine* assimilation and distribution by actual marine fauna (conchs, gasteropods), suggesting that iodine* is concentrated in some specific parts of the organism, such as the operculum (Ishii, 1997; Vives I Batlle et al., 2005). Additional EPMA data on phosphatic bioclasts (Figure 7f) strongly suggest that these organisms do not significantly incorporate iodine* in their structure. 
lodine* was also detected in late diagenetic euhedral carbonates (calcite and dolomite up to $621 \mathrm{mg} / \mathrm{kg}$, figure $7 \mathrm{~g}$ and $7 \mathrm{~h}$ ). This result suggests that part of the iodine* originally trapped by biocarbonates and released after partial dissolution during diagenesis could be trapped again by late diagenetic euhedral carbonates

\subsection{3. lodine* in carbonate: a realistic assumption?}

Based on chemical extractions and EPMA analyses, iodine* in COx clay rock samples was found to be essentially carried by carbonate bioclasts and marine-derived organic matter. Based on our results, a rough estimation of the concentration in the inorganic and organic compartments should be around $2 \mathrm{ppm}$ of iodine* in the carbonate fraction (variation range measured between 1.7 and 2.5) and $0.3 \mathrm{ppm}$ in the accessible organic matter (variation range measured between 0 and 0.6 ). The fact that most of the iodine* is associated with carbonate is to our knowledge seldom described in the literature in comparison to the huge amount of articles describing a strong affinity between iodine* and organic matter. However, assuming an analogy between iodide and fluoride, it might be possible for iodide to be trapped in a Ca-Mg carbonate matrix as has been demonstrated for fluoride (Kitano and Okumura, 1973; Ohde and Kitano, 1980). Furthermore, high concentration of iodine* in carbonate rich sediments has already been demonstrated (Bennett and Manuel, ; Kennedy and Elderfield, 1987; Muramatsu and Wedepohl, 1998). Muramatsu and Wedepohl (1998) found that nearshore carbonates contain 10 times less iodine* than deep-sea carbonates. They explain this difference by the much lower preserved organic carbon content of the former sediments, whereas in the latter sediments planktonic foraminifera, which already primarily consist of low magnesium calcite, will be less diagenetically altered. Our observations with EPMA effectively showed that foraminifera contain iodine*, but the chemical extractions rather suggest an association with carbonate in an inorganic form. This is in contradiction with the aforementioned argument for organic carbon preservation, which implies that iodine* is fixed in the organic part of the organism. 


\section{CONCLUSIONS AND METHODOLOGICAL IMPLICATIONS FOR IODINE* FATE PREDICTIONS IN GEOLOGICAL DISPOSALS}

The present study confirmed the ubiquitous presence of iodine* at $1-5 \mathrm{mg} \mathrm{kg}^{-1}$ level in the COx clayey formation. The $\mathrm{I}^{-}$level or concentration in the porewater is also confirmed at a value in the range $\sim 20-40 \mu \mathrm{mol} \mathrm{L^{-1 }}$. With regards to $\mathrm{I}^{-}$retention in the far-field of geological disposal, i.e. in undisturbed conditions, these results are in agreement with the range of $\mathrm{Kd}$ values that could be due to isotopic exchange given by Tournassat et al. (2007) (0.2 to $2 \mathrm{~L}$ $\mathrm{kg}^{-1}$ ). We have also shown that most of the iodine* is trapped in the carbonate minerals of the formation. Given the expected very low solid diffusion of iodine* in these structures, most of the natural iodine* would not be accessible for isotopic exchange with radioactive iodine*, thereby reducing the resulting $\mathrm{Kd}$ to negligible values (note that the highest computed natural $\mathrm{Kd}$ values correspond to carbonate rich layers).

In the context of the disturbed near-field area of the disposal, the present results show that retention of $\mathrm{I}^{-}$during precipitation of carbonate minerals is potentially feasible. Further studies should be conducted to validate the iodide/fluoride analogy in carbonate matrix and to derive solubility parameters. Such a retention process would also necessitate that the extent of the I' plume coincides with the disturbance that is responsible for such carbonate mineral precipitation. Although, this last scenario would be difficult to assess, it has also a great implication for experimental work in the laboratory. Most studies showing retention of $\mathrm{I}^{-}$on clayey samples also show problems of irreversibility of the phenomenon (e.g. Wittebroodt et al. 2008). Glaus et al. (2008) have shown that the redox state of the $\mathrm{I}^{-}$tracer can be responsible for strong experimental artefacts: the use of a chromatographic column to work with pure $\mathrm{I}^{-}$tracer (or, at least to verify that any pre-treatment of the tracer led to the desired redox state of the tracer) seems then to be a prerequisite for I' retention studies. The work by Bazer-Bachi et al. (2006) has also clearly shown that it is very important to work on nonoxidized samples and under anoxic atmosphere conditions. In addition, from the present study, it can be foreseen that the absence of a rigorous control of the carbonate system (equilibrium of calcite/dolomite with a given $\mathrm{CO}_{2}$ partial pressure $\mathrm{P}_{\mathrm{CO} 2}$ ) could also lead to an experimental artefact through the incorporation of $\mathrm{I}^{-}$in a newly precipitated carbonate phase. A good control of the geochemical parameters $\left(\mathrm{pH}, \mathrm{P}_{\mathrm{CO} 2}\right.$, calcium, $\mathrm{Mg}$ concentrations that have been measured and also calculated, (Gaucher et al., 2006; Vinsot et al., 2008)) is then 
mandatory to enable a rigorous interpretation of the diffusion/retention experiments. However, such control in a batch system is often difficult for two reasons: the anoxic $\mathrm{N}_{2}$ atmospheres in glove boxes are usually very depleted in $\mathrm{CO}_{2}$, leading in turn to easy $\mathrm{CO}_{2}$ degassing of the studied solutions and possible carbonate precipitation. It is possible to avoid this problem by working in a $\mathrm{N}_{2} / \mathrm{CO}_{2}$ atmosphere with $\mathrm{CO}_{2}$ partial pressure at equilibrium value with calcite/dolomite and the solute calcium/magnesium concentrations. Natural minerals have solubility values slightly different from those tabulated in the thermodynamics database (due to database uncertainties but also to impurities, like iron, in their structure). As a consequence, a pre-equilibration period would be necessary prior to the introduction of the tracer in the experiments. For diffusion experiments, this pre-equilibration is fortunately usually achieved during the resaturation of the samples.

With the present state of the art about I- retention in clay formations such as COx or Opalinus clay, we consider that a retardation factor different from 0 would be difficult to assess unambiguously. At the least, the recommendations above should be strictly respected during any further experimental work. Currently, only one study can be considered to fulfil these requirements and its conclusion is that no retardation has been noticed for $\mathrm{I}^{-}$as compared to chloride (Glaus et al. 2008).

\section{Acknowledgements}

The results presented in this article were collected during the GL-Transfert Project granted by ANDRA in the framework of the ANDRA/BRGM scientific partnership. C. Mariet (CEA) and R. Jacimovic and V. Stibilj (Josef Stefan Institute) are acknowledged for the both the INAA and RNAA measurements. G. Braibant is thanked for sample preparation. We are grateful to $\mathrm{Dr}$ G. Connelly (Scientific Translations Limited) for proofreading and editing the English text. The associate editor and three anonymous referees are thanked for their constructive comments. 


\section{REFERENCES}

Altmann, S., 2008. 'Geo'chemical research: A key building block for nuclear waste disposal safety cases. J. Contam. Hydrol. 102, 174-179.

Ancey, M., Bastenaire, F., and Tixier, R., 1977a. Precision and optimization of electron-probe analysis of thin specimens. Journal de microscopie et de spectroscopie electroniques 2, 169-170.

Ancey, M., Bastenaire, F., and Tixier, R., 1977b. Statistical control and optimization of X-Ray intensity measurements. J. Phys. D: Appl. Phys. 10, 817-830.

Andra, 2005. Dossier 2005 Argile. Les recherches de l'Andra sur le stockage géologique des déchets radioactifs à haute activité et à vie longue, http://www.andra.fr.

Appelo, C. A. J., Vinsot, A., Mettler, S., and Wechner, S., 2008. Obtaining the porewater composition of a clay rock by modeling the in- and out-diffusion of anions and cations from an in-situ experiment. J. Contam. Hydrol. 101 67-76.

Bazer-Bachi, F., Tevissen, E., Descostes, M., Grenut, B., Meier, P., Simonnot, M. O., and Sardin, M., 2006. Characterization of iodide retention on Callovo-Oxfordian argillites and its influence on iodide migration. Phys. Chem. Earth. 31, 517-522.

Bennett, J. H. and Manuel, O. K., 1968. On lodine Abundances in Deep-Sea Sediments. J. Geophys. Res. 73.

Bing, L., Ma, X. R., Han, L. R., and Yang, H. X., 2004. Pressurised extraction using dilute ammonia: A simple method for determination of iodine in soil, sediment and biological samples by inductively coupled plasma-mass spectrometry. Geostand. Geoanal. Res. 28, 317-323.

Carpentier, C., Breton, G., Huault, V., and Lathuiliere, B., 2006. Decapods crustaceans from the Kimmeridgian of Bure (Lorraine, France). Geobios 39, 617-629.

Claret, F., Sakharov, B. A., Drits, V. A., Velde, B., Meunier, A., Griffault, L., and Lanson, B., 2004. Clay minerals in the Meuse-Haute Marne underground laboratory (France): Possible influence of organic matter on clay mineral evolution. Clay. Clay. Miner. 52, 515-532.

Claret, F., Schafer, T., Rabung, T., Wolf, M., Bauer, A., and Buckau, G., 2005. Differences in properties and $\mathrm{Cm}$ (III) complexation behavior of isolated humic and fulvic acid derived from Opalinus clay and Callovo-Oxfordian argillite. Appl. Geochem. 20, 1158-1168.

Courdouan, A., Christl, I., Meylan, S., Wersin, P., and Kretzschmar, R., 2007. Isolation and characterization of dissolved organic matter from the Callovo-Oxfordian formation. Appl. Geochem. 22, 1537-1548.

Danzer, K., 2006. Analytical Chemistry. Theoretical and Metrological Fundamentals. Springer. 
De Corte, F. and Simonits, A., 2003. Recommended nuclear data for use in the k0 standardization of neutron activation analysis. Atom. Data Nucl. Data 85, 47-67.

De Craen, M., Van Geet, M., Wang, L., and Put, M., 2004. High sulphate concentrations in squeezed Boom Clay pore water: evidence of oxidation of clay cores. Phys. Chem. Earth. 29, 91-103.

Deniau, I., Devol-Brown, I., Derenne, S., Behar, F., and Largeau, C., 2008. Comparison of the bulk geochemical features and thermal reactivity of kerogens from Mol (Boom Clay), Bure (Callovo-Oxfordian argillite) and Tournemire (Toarcian shales) underground research laboratories. Sci. Tot. Env. 389, 475-485.

Dermelj, M., Slejkovec, Z., Byrne, A. R., Stegnar, P., Stibilj, V., and Rossbach, M., 1990. lodine in Different Food Articles and Standard Reference Materials. Fresenius $\mathrm{J}$. Anal. Chem. 338, 559-561.

Descostes, M., Blin, V., Bazer-Bachi, F., Meier, P., Grenut, B., Radwan, J., Schlegel, M. L., Buschaert, S., Coelho, D., and Tevissen, E., 2008. Diffusion of anionic species in Callovo-Oxfordian argillites and Oxfordian limestones (Meuse/Haute-Marne, France). Appl. Geochem. 23, 655-677.

Disnar, J. R., Le Strat, P., Farjanel, G., and Fikri, A., 1996. Sédimentation de la matière organique dans le nord-est du Bassin de Paris: conséquences sur le dépôt des argilites carbonées du Toarcien inférieur. Chem. Geol. 131, 15-35.

Dromart, G., Garcia, J. P., Gaumet, F., Picard, S., Rousseau, M., Atrops, F., Lecuyer, C., and Sheppard, S. M. F., 2003. Perturbation of the carbon cycle at the Middle/Late Jurassic transition: Geological and geochemical evidence. Am. J. Sci. 303, 667-707.

Ebihara, M., Ozaki, H., Kato, F., and Nakahara, H., 1997. Determination of chlorine, bromine and iodine in rock samples by radiochemical neutron activation analysis. J. Radioan. Nucl. Chem. 216, 107-112.

Ebihara, M., Saito, N., Akaiwa, H., and Tomura, K., 1992. Instrumental and Radiochemical Neutron-Activation Analysis of Trace lodine in Geological Samples. Anal. Sci. 8, 183187.

Elie, M., Faure, P., Michels, R., Landais, P., and Griffault, L., 2000. Natural and laboratory oxidation of low-organic-carbon-content sediments: comparison of chemical changes in hydrocarbons. Energy Fuels 14, 854-861.

Fuge, R. and Johnson, C. C., 1986. The Geochemistry of lodine - a Review. Environ. Geochem. Health 8, 31-54.

Gaucher, E., Robelin, C., Matray, J. M., Negral, G., Gros, Y., Heitz, J. F., Vinsot, A., Rebours, H., Cassagnabere, A., and Bouchet, A., 2004. ANDRA underground research laboratory: interpretation of the mineralogical and geochemical data acquired in the Callovian-Oxfordian formation by investigative drilling. Phys. Chem. Earth. 29, 55-77.

Gaucher, E., Tournassat, C., Pearson, F. J., P., B., Crouzet, C., Lerouge, C., and Altmann, S., accepted. Robust model for clay rock porewater chemistry. Geochim. Cosmochim. Acta.

Gaucher, E. C., Blanc, P., Bardot, F., Braibant, G., Buschaert, S., Crouzet, C., Gautier, A., Girard, J. P., Jacquot, E., Lassin, A., Negrel, G., Tournassat, C., Vinsot, A., and 
Altmann, S., 2006. Modelling the porewater chemistry of the Callovian-Oxfordian formation at a regional scale. Comptes Rendus Geoscience 338, 917-930.

Glaus, M. A., Müller, W., and Van Loon, L. R., 2008. Diffusion of iodide and iodate through Opalinus Clay: Monitoring of the redox state using an anion chromatographic technique. Appl. Geochem. 23, 3612-3619.

Grambow, B., 2008. Mobile fission and activation products in nuclear waste disposal. J. Contam. Hydrol. 102, 180-186.

Hautevelle, Y., Michels, R., Malartre, F., Elie, M., and Trouiller, A., 2007. Tracing of variabilities within a geological barrier by molecular organic geochemistry. Case of the Callovo-Oxfordian sedimentary series in the East of the Paris Basin (France). Appl. Geochem. 22, 736-759.

Hou, X. L., Fogh, C. L., Kucera, J., Andersson, K. G., Dahlgaard, H., and Nielsen, S. P., 2003. Iodine-129 and Caesium-137 in Chernobyl contaminated soil and their chemical fractionation. Sci. Tot. Env. 308, 97-109.

Ishii, T., 1997. Specific accumulation of iodine by the operculum of the strawberry conch Strombus luhuanus. Fish. Sci. 63, 646-647.

Jones, G. B., Belling, G. B., and Buckley, R. A., 1979. Recovery of lodine as I-125 from Biological-Materials Prior to Assay. Analyst 104, 469-471.

Kennedy, H. A. and Elderfield, H., 1987. Iodine Diagenesis in Pelagic Deep-Sea Sediments. Geochim. Cosmochim. Acta 51, 2489-2504.

Kitano, Y. and Okumura, M., 1973. Coprecipitation of fluoride with calcium carbonate. Geochem. J. 7, 37-49.

Koch-Steindl, H. and Prohl, G., 2001. Considerations on the behaviour of long-lived radionuclides in the soil. Radiat. Environ. Bioph. 40, 93-104.

Landais, P. and Elie, M., 1999. Utilisation de la géochimie organique pour la détermination du paléoenvironnement et de la paléothermicité dans le Callovo-Oxfordien du site de I'Est de la france. Etude de I'Est du bassin de ParisEdition EDP Sciences.

Lerouge, C., Michel, P., Gaucher, E. C., and Tournassat, C., 2006. A geological, mineralogical and geochemical GIS for the Andra URL: A tool for the water-rock interactions modelling at a regional scale. In: SKB (Ed.),FUNMIG - 2nd annual workshop, Stockholm-Sweden.

Li, B., He, H. L., Shi, S. Y., Ma, X. R., Wen, H. L., and Lu, C. F., 2002. Simultaneous determination of iodine, bromine, selenium and arsenic in geological samples by inductively coupled plasma mass spectrometry. J. Anal. At. Spectrom. 17, 371-376.

Marchetti, A. A., Rose, L., and Straume, T., 1994. A Simple and Reliable Method to Extract and Measure lodine in Soils. Anal. Chim. Acta 296, 243-247.

Michel, A. and Villemant, B., 2003. Determination of halogens ( $\mathrm{F}, \mathrm{Cl}, \mathrm{Br}, \mathrm{I})$, sulfur and water in seventeen geological reference materials. Geostandards Newsletter-the Journal of Geostandards and Geoanalysis 27, 163-171. 
Moran, J. E., Teng, R. T. D., Rao, U., and Fehn, U., 1995. Detection of lodide in Geologic Materials by High-Performance Liquid-Chromatography. J. Chromatogr., A 706, $215-$ 220.

Muramatsu, Y., Fehn, U., and Yoshida, S., 2001. Recycling of iodine in fore-arc areas: evidence from the iodine brines in Chiba, Japan. Earth Planet. Sci. Lett. 192, 583593.

Muramatsu, Y. and Wedepohl, K. H., 1998. The distribution of iodine in the earth's crust. Chem. Geol. 147, 201-216.

Ohde, S. and Kitano, Y., 1980. Incorporation of Fluoride into Ca-Mg Carbonate. Geochem. J. 14, 321-324.

Osterc, A., Jacimovic, R., and Stibilj, V., 2007. Development of a method for I-129 determination using radiochemical neutron activation analysis. Acta Chim. Slov. 54, 273-283.

Osterc, A. and Stibilj, V., 2005. Measurement uncertainty of iodine determination in radiochemical neutron activation analysis. Accredit. Qual. Assur. 10, 235-240.

Ozaki, H. and Ebihara, M., 2007. Determination of trace halogens in rock samples by radiochemical neutron activation analysis coupled with the $\mathrm{k}(0)$-standardization method. Anal. Chim. Acta 583, 384-391.

Pearson, F. J., 1999. What is the porosity of a mudrock. In: Aplin, A. C., Fleet, A. F., and Macquaker, J. Eds.), Physical properties of muds and mudstones. Geological Society Special Publication, London.

Pearson, F. J., Arcos, D., Boisson, J.-Y., Fernandez, A. M., Gäbler, H.-E., Gaucher, E., Gautschi, A., Griffault, L., Hernan, P., and Waber, H. N., 2003. Mont Terri project Geochemistry of water in the Opalinus clay formation at the Mont Terri Rock Laboratory. In: F.O.W.G (Ed.), Bern.

Pearson, F. J. and Waber, H. N., 2001. Origin and evolution of pore-water solutes in the very-low permeability Opalinus Clay, Switzerland. Water-Rock Interaction, Vols 1 and 2, 1355-1358.

Pellenard, P., Deconinck, J. F., Marchand, D., Thierry, J., Fortwengler, D., and Vigneron, G., 1999. Eustatic and volcanic influence during Middle Callovian Oxfordian clay sedimentation in the eastern part of the Paris Basin. Compte rendus de l'academie des sciences 328, 807-813.

Quevauviller, P., 1998. Operationally defined extraction procedures for soil and sediment analysis - II. Certified reference materials. Trac-Trend Anal. Chem. 17, 632-642.

Schafer, T., Michel, R., Claret, F., Beetz, T., Wirick, S., and Jacobsen, C., 2009. Radiation sensitivity of natural organic matter: Clay mineral association effects in the CallovoOxfordian argillite. J. Electron Spectrosc. Relat. Phenom. 170, 49-56.

Schlegel, M. L., Reiller, P., Mercier-Bion, F., Barre, N., and Moulin, V., 2006. Molecular environment of iodine in naturally iodinated humic substances: Insight from X-ray absorption spectroscopy. Geochim. Cosmochim. Acta 70, 5536-5551. 
Sun, F. S. and Julshamn, K., 1987. An Indirect Determination of lodine Using Hgin Complexes and Cold Vapor Atomic-Absorption Determination of Mercury. Spectrochim. Acta, Part B 42, 889-894.

Sweatman, T. R. and Long, J. V. P., 1969. Quantitative Electron-probe Microanalysis of Rock-forming Minerals. J. Petrology 10, 332-379.

Tagami, K. and Uchida, S., 2005. Sample storage conditions and holding times for the determination of total iodine in natural water samples by ICP-MS. At. Spectrosc. 26, 209-214.

Tessier, A., Campbell, P. G. C., and Bisson, M., 1979. Sequential extraction procedure for the speciation of particulate trace metals. Anal. Chem 51, 844-851.

Tournassat, C., Gaucher, E. C., Fattahi, M., and Grambow, B., 2007. On the mobility and potential retention of iodine in the Callovian-Oxfordian formation. Phys. Chem. Earth. 32, 539-551.

Tournassat, C., Lerouge, C., Blanc, P., Brendle, J., Greneche, J. M., Touzelet, S., and Gaucher, E. C., 2008. Cation exchanged Fe(II) and Sr compared to other divalent cations ( $\mathrm{Ca}, \mathrm{Mg})$ in the Bure Callovian-Oxfordian formation: Implications for porewater composition modelling. Appl. Geochem. 23, 641-654.

Van Loon, L. R., Soler, J. M., and Bradbury, M. H., 2003. Diffusion of HTO, Cl-36(-) and I$125(-)$ in Opalinus Clay samples from Mont Terri - Effect of confining pressure. J. Contam. Hydrol. 61, 73-83.

Vinsot, A., Mettler, S., and Wechner, S., 2008. In situ characterization of the CallovoOxfordian pore water composition. Phys. Chem. Earth. 33, S75-S86.

Vives I Batlle, J., Wilson, R. C., Mcdonald, P., and Parker, T. G., 2005. Uptake and depuration of I-131 by the edible periwinkle Littorina littorea: uptake from seawater. $J$. Envir. Radioactiv. 78, 51-67.

Wifladt, A. M., Lund, W., and Bye, R., 1989. Determination of lodine in Seaweed and Table Salt by an Indirect Atomic-Absorption Method. Talanta 36, 395-399.

Wittebroodt, C., Savoye, S., and Gouze, P., 2008. Influence of initial iodide concentration on the iodide uptake by the argillite of Tournemire. Phys. Chem. Earth. 33, 943-948. 


\section{Tables}

Table 1: lodine* content (RNAA measurement), total organic carbon (TOC) and carbonate contents within different size fractions of the COx reference sample

\begin{tabular}{cccc}
\hline Size fractions & $\begin{array}{c}\text { lodine* }^{*}(\mathrm{mg} / \mathrm{kg}) \\
\text { Analytical } \\
\text { uncertainty } 4 \%\end{array}$ & $\begin{array}{c}\text { TOC }(\%) \\
\text { Analytical } \\
\text { uncertainty } 10 \%\end{array}$ & $\begin{array}{c}\text { Carbonate (\%) } \\
\text { Analytical } \\
\text { uncertainty } 2 \%\end{array}$ \\
$\begin{array}{c}32-40 \mu \mathrm{m} \\
20-32 \mu \mathrm{m}\end{array}$ & 5.1 & n.d. & 28 \\
$10-20 \mu \mathrm{m}$ & 5.0 & n.d. & 23 \\
$7-10 \mu \mathrm{m}$ & 4.7 & 0.36 & 20 \\
$5-7 \mu \mathrm{m}$ & 3.7 & 0.44 & 20 \\
$3.5-5 \mu \mathrm{m}$ & 3.2 & 0.72 & 14 \\
$1-3.5 \mu \mathrm{m}$ & 3.0 & 0.83 & n.d. \\
$<1 \mu \mathrm{m}$ & 1.3 & 0.91 & n.d. \\
$\begin{array}{c}\text { Total recalculated } \\
\text { from weight }\end{array}$ & 1.1 & 1.19 & \\
$\begin{array}{c}\text { percentage of } \\
\text { each size fraction }\end{array}$ & 3.1 & 0.95 & \\
$\begin{array}{c}\text { Total, measured } \\
\text { on raw sample }\end{array}$ & 4.3 & & \\
\hline
\end{tabular}


Table 2: Determination of total iodine ${ }^{*}$ concentration in the COx reference sample and in an international certified standard using four different analytical methods.

\begin{tabular}{|c|c|c|c|}
\hline & & $\begin{array}{l}\text { COx reference } \\
\text { sample }\end{array}$ & $\begin{array}{c}\text { Standard GBW07311 } \\
\text { Certified value } 2 \pm 0.2 \mathrm{mg} / \mathrm{kg}\end{array}$ \\
\hline Technique used & $\begin{array}{l}\text { Analytical } \\
\text { uncertainty }\end{array}$ & $\begin{array}{l}\text { Concentration } \\
\qquad(\mathrm{mg} / \mathrm{kg})\end{array}$ & Concentration $(\mathrm{mg} / \mathrm{kg})$ \\
\hline $\mathrm{HNO}_{3} / 90^{\circ} \mathrm{C}$ /one night & $10 \%^{1}$ & 2.6 & 2.0 \\
\hline $\mathrm{NH}_{3} 10 \% \mathrm{Vol} / 185^{\circ} \mathrm{C} /$ one night & $10 \%{ }^{1}$ & 0.3 & 2.1 \\
\hline RNAA (Josef Stefan Institute) & $4 \%^{2}$ & 4.6 & 2.1 \\
\hline INAA (Pierre Sue Institute) & $10 \%^{3}$ & 3.5 & - \\
\hline \multicolumn{4}{|l|}{${ }^{1}$ (coverage factor $\mathrm{k}=2$ ) } \\
\hline \multicolumn{4}{|l|}{${ }^{2}$ (Osterc and Stibilj, 2005), } \\
\hline${ }^{3}$ Given by Pierre Sue Institute (c & herag fonto & $=3)$ & \\
\hline
\end{tabular}


Table 3: lodine* distribution within the reference COx sample according to sequential extraction procedures

\begin{tabular}{|c|c|c|c|c|c|c|c|c|c|c|c|c|c|}
\hline \multirow{2}{*}{$\begin{array}{c}\begin{array}{c}\text { Name of the } \\
\text { fraction }\end{array} \\
\text { according to the } \\
\text { Tessier method } \\
(1979)\end{array}$} & \multirow{2}{*}{$\begin{array}{c}\begin{array}{c}\text { Calculated } \\
\text { uncertainty }\end{array} \\
10 \%\end{array}$} & \multicolumn{8}{|c|}{ lodine ${ }^{*}$ content $(\mathrm{mg} / \mathrm{kg})$ Oxic extraction/Acetic acid } & \multirow{2}{*}{ 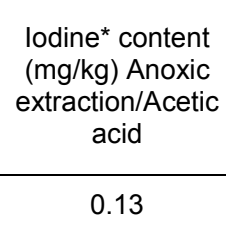 } & \multicolumn{3}{|c|}{$\begin{array}{l}\text { lodine* content } \\
(\mathrm{mg} / \mathrm{kg}) \text { Oxic } \\
\text { extraction/HCl }\end{array}$} \\
\hline & & 0.18 & 0.19 & 0.18 & 0.17 & 0.19 & 0.23 & 0.20 & 0.24 & & 0.12 & 0.12 & 0.12 \\
\hline $\begin{array}{l}\text { Exchangeable } \\
\text { fraction }\end{array}$ & Not relevant & 0 & 0 & 0 & 0 & 0 & 0 & 0 & 0 & 0 & 0 & 0 & 0 \\
\hline $\begin{array}{l}\text { Carbonate } \\
\text { fraction }\end{array}$ & $11 \%$ & 1.6 & 2.2 & 2.0 & 2.4 & 1.5 & 1.3 & 1.1 & 1.6 & 2.2 & 2.0 & 2.1 & 2.1 \\
\hline $\begin{array}{l}\text { Organic matter } \\
\text { fraction }\end{array}$ & $18 \%$ & 0.6 & 0 & 0 & 0 & 1.0 & 1.0 & 1.2 & 0.7 & 0 & 0 & 0 & 0 \\
\hline Total & $11 \%$ & 2.40 & 2.43 & 2.21 & 2.55 & 2.68 & 2.53 & 2.56 & 2.57 & 2.34 & 2.10 & 2.27 & 2.20 \\
\hline
\end{tabular}

${ }^{1}$ after (Danzer, 2006) with coverage factor $\mathrm{k}=2$ 


\section{Figure captions}

Figure 1: Sample localisation around the URL (Underground Research Laboratory)

Figure 2 : Lithostratigraphy and mineralogy of the studied boreholes. In the analyses column (right column), the black circles and open squares indicate chemical analyses and electron microprobe analyses respectively. URL level indicates the Underground Research Laboratory level.

Figure 3: Spectrum of the Ca-K X-ray emission lines in the apatite standard on one spectrometer equipped with PET crystals and position of the I-L X-ray emission lines and the backgrounds used for the two analytical conditions.

Figure 4: Total iodine* content as a function of organic matter content (left) and carbonate content (right) of the reference COx sample ( EST 26479) size fractions (Table 1). 30

Figure 5: Total iodine* content (symbols, measured after $\mathrm{HNO}_{3}$ digestion at $90^{\circ} \mathrm{C}$ overnight) and carbonate content (lines) as a function of depth. All the depths have been calculated according to both the hanging and the foot wall of the borehole EST 212. Different symbols indicate different borehole locations as indicated by the caption on the right (refer to Figure 1 for localisation).

Figure 6: Micrographs of 3 black particles of organic matter in natural transmitted light (left side) and in reflected light (right side). a) semi-fusinite, b) first vitrinite sample, c) second vitrinite sample.

Figure 7: a-b: transmitted light and reflected light - a pyrite + organic matter zone - sample EST25687. c: transmitted light - cross-section of a terebratula shell formed by alternations of fibrous calcite (or aragonite) - sample EST12436. d - Transmitted light - unknown fossil EST 25687.e - Transmitted light - shell formed by fibrous calcite - EST25687.f Transmitted light - honey coloured phosphatic clast without structure - EST25687. g Transmitted light - euhedral grain of calcite (Cc) - EST 25380. h - Transmitted light euhedral grain of dolomite (Dol) - EST 25380. 


\section{Figures}

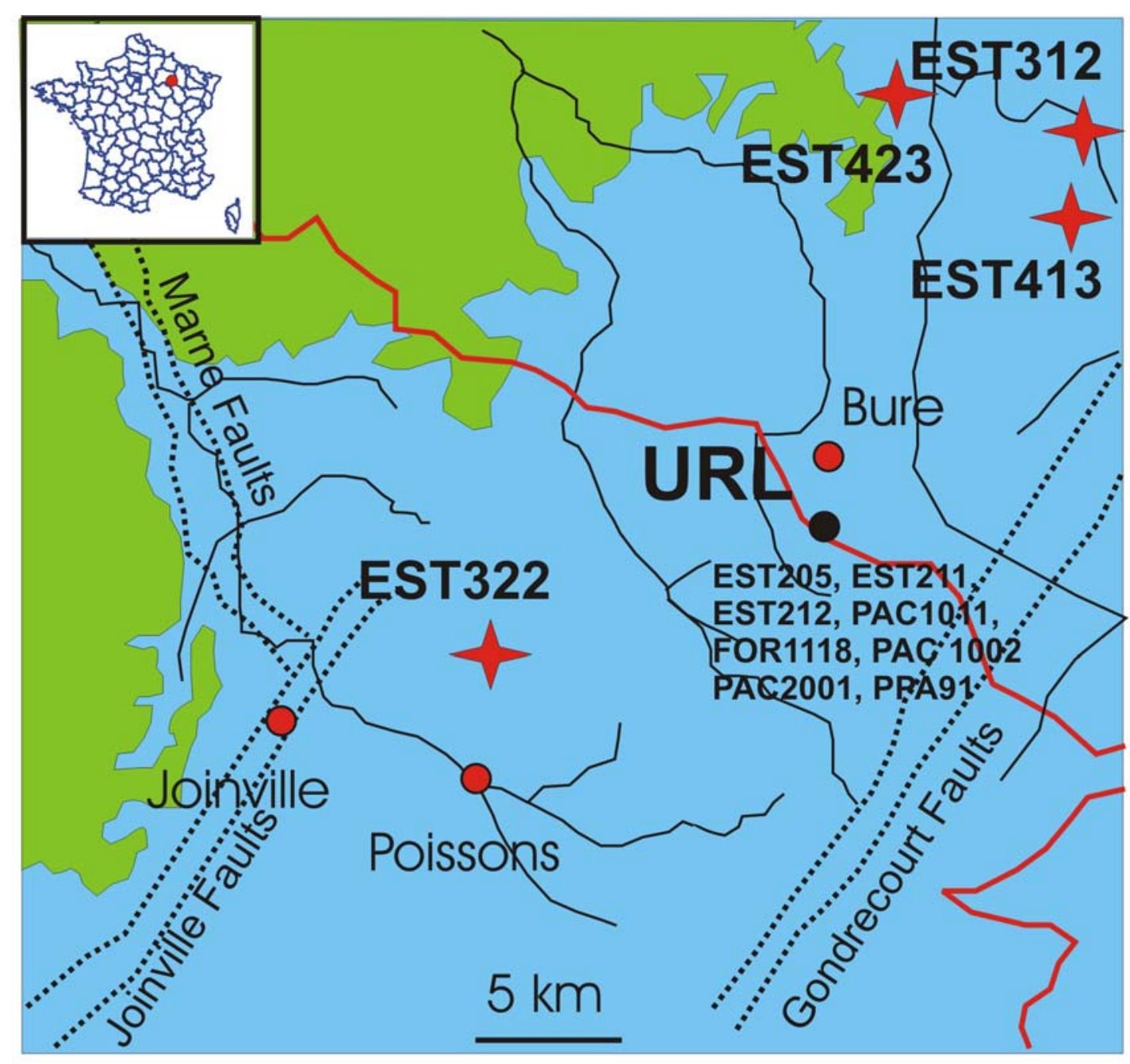

Lower Cretaceous

Middle and Upper Jurassic
Faults

French department boundaries

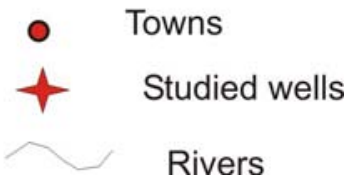

Rivers

Figure 1: Sample localisation around the URL (Underground Research Laboratory) 


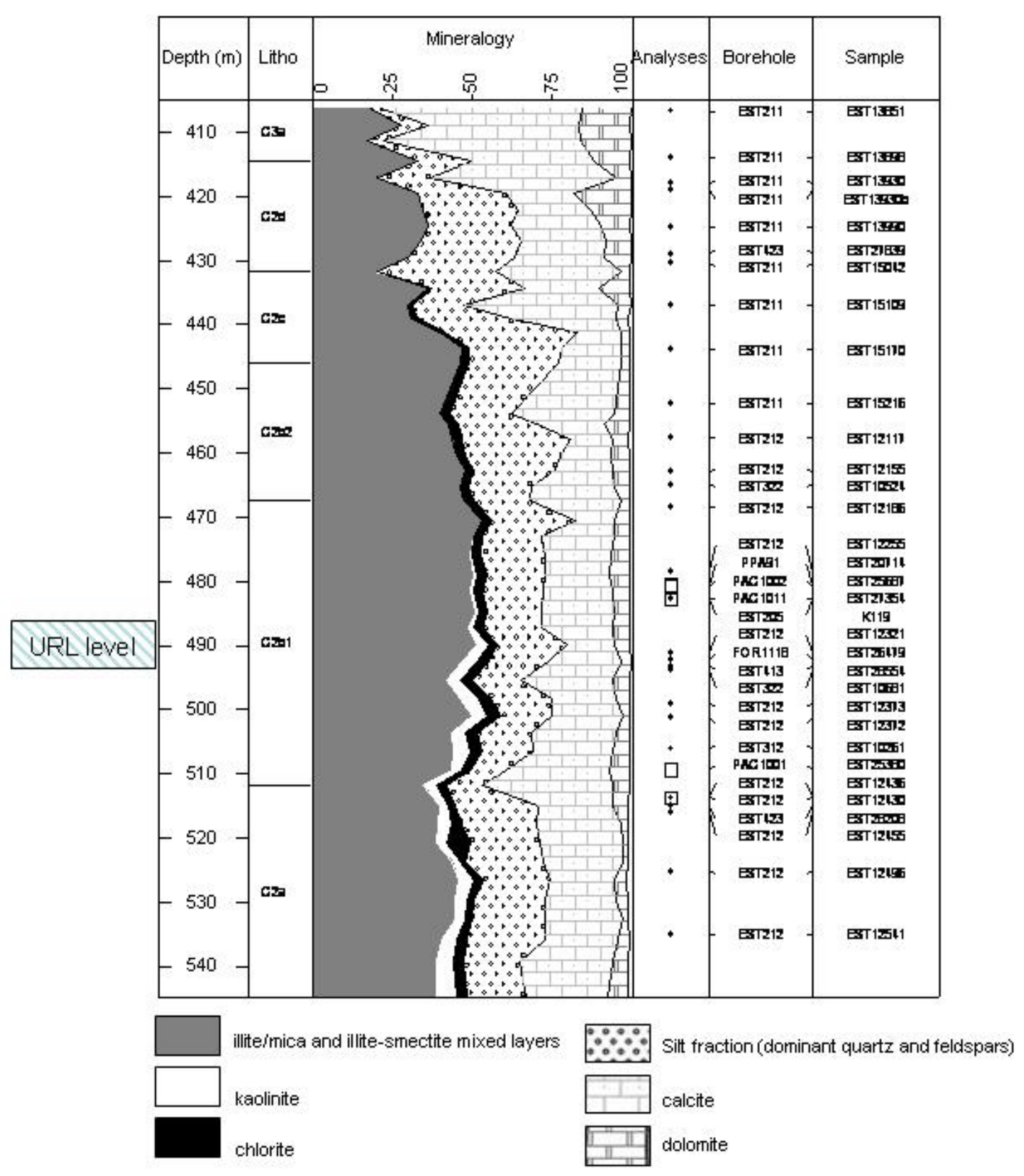

Figure 2 : Lithostratigraphy and mineralogy of the studied boreholes. In the analyses column (right column), the black circles and open squares indicate chemical analyses and electron microprobe analyses respectively. URL level indicates the Underground Research Laboratory level. 


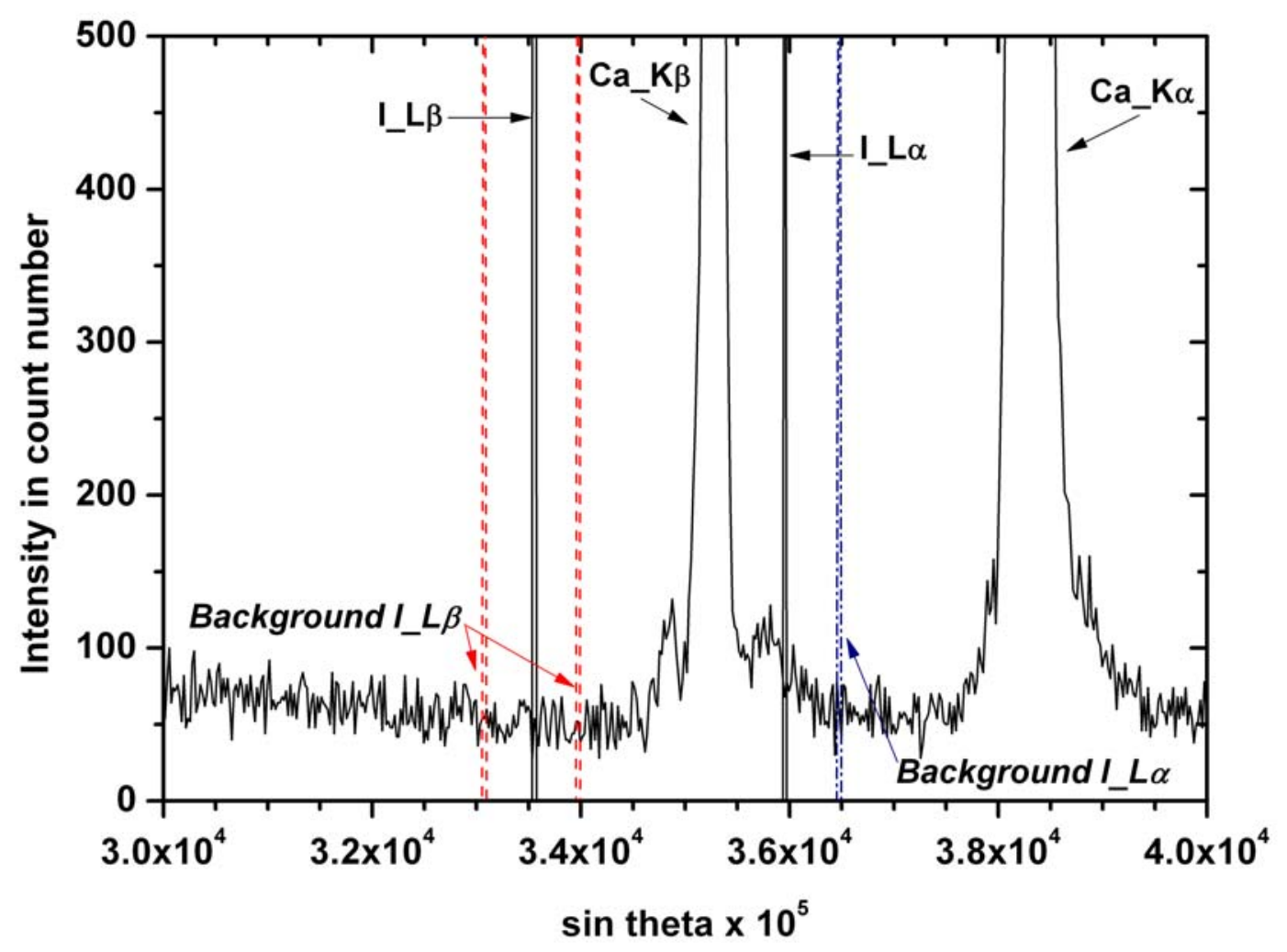

Figure 3: Spectrum of the Ca-K X-ray emission lines in the apatite standard on one spectrometer equipped with PET crystals and position of the I-L X-ray emission lines and the backgrounds used for the two analytical conditions. 

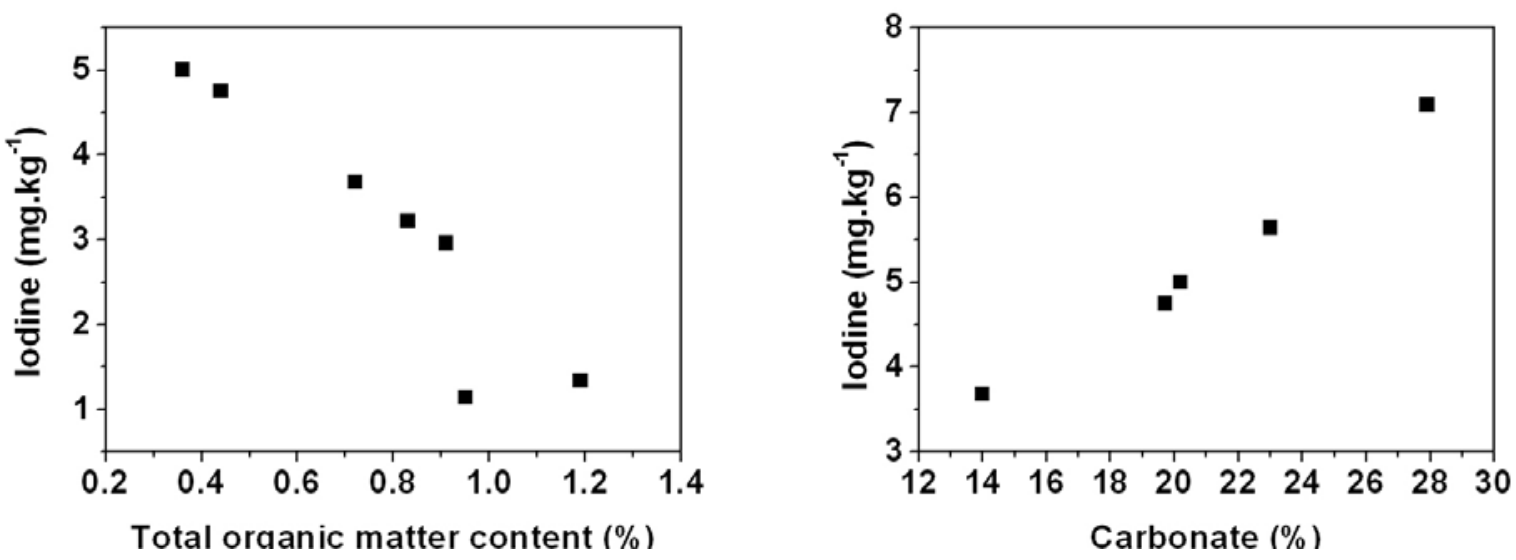

Figure 4: Total iodine* content as a function of organic matter content (left) and carbonate content (right) of the reference COx sample ( EST 26479) size fractions (Table 1). 


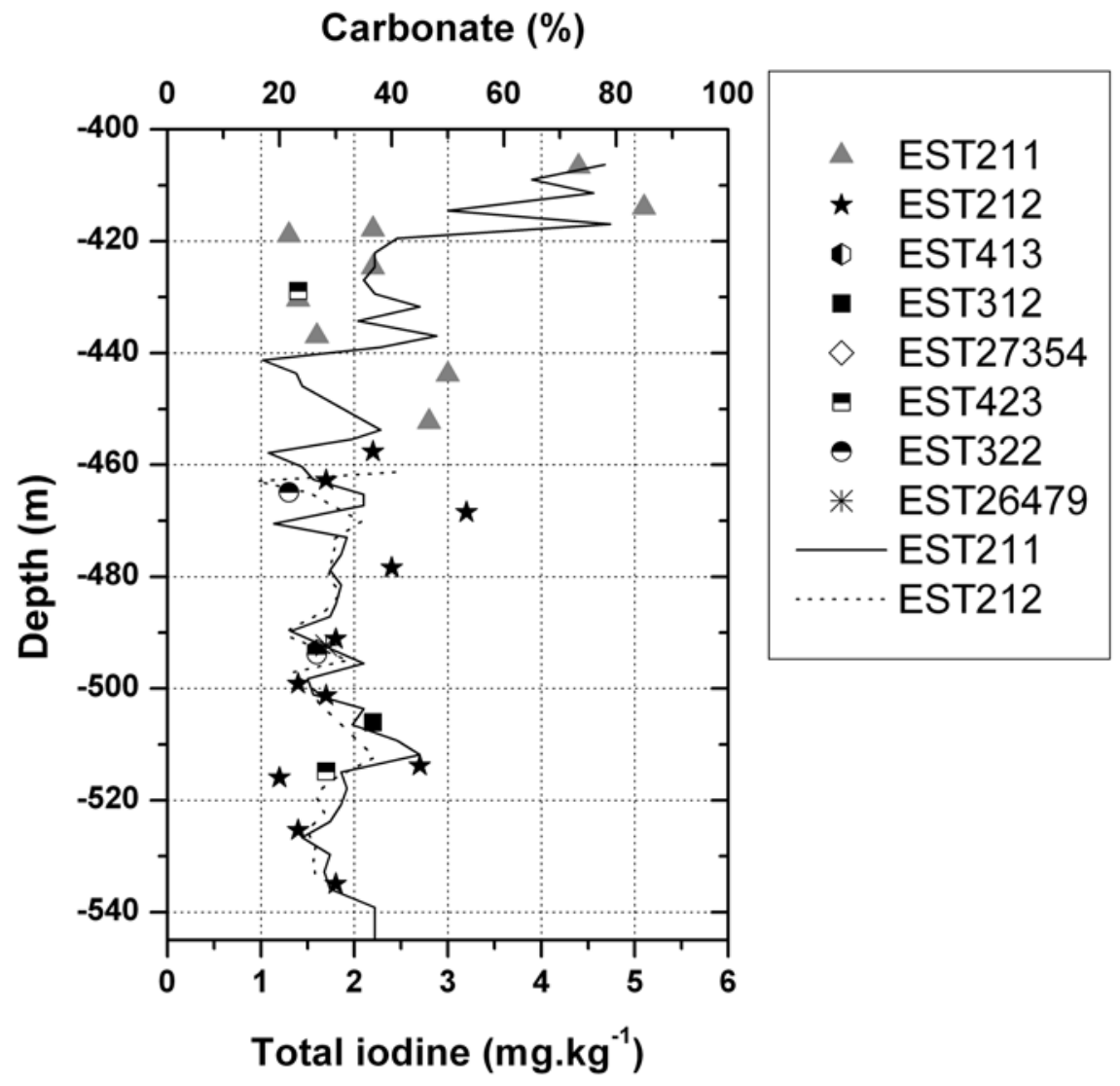

Figure 5: Total iodine* content (symbols, measured after $\mathrm{HNO}_{3}$ digestion at $90^{\circ} \mathrm{C}$ overnight) and carbonate content (lines) as a function of depth. All the depths have been calculated according to both the hanging and the foot wall of the borehole EST 212. Different symbols indicate different borehole locations as indicated by the caption on the right (refer to Figure 1 for localisation). 

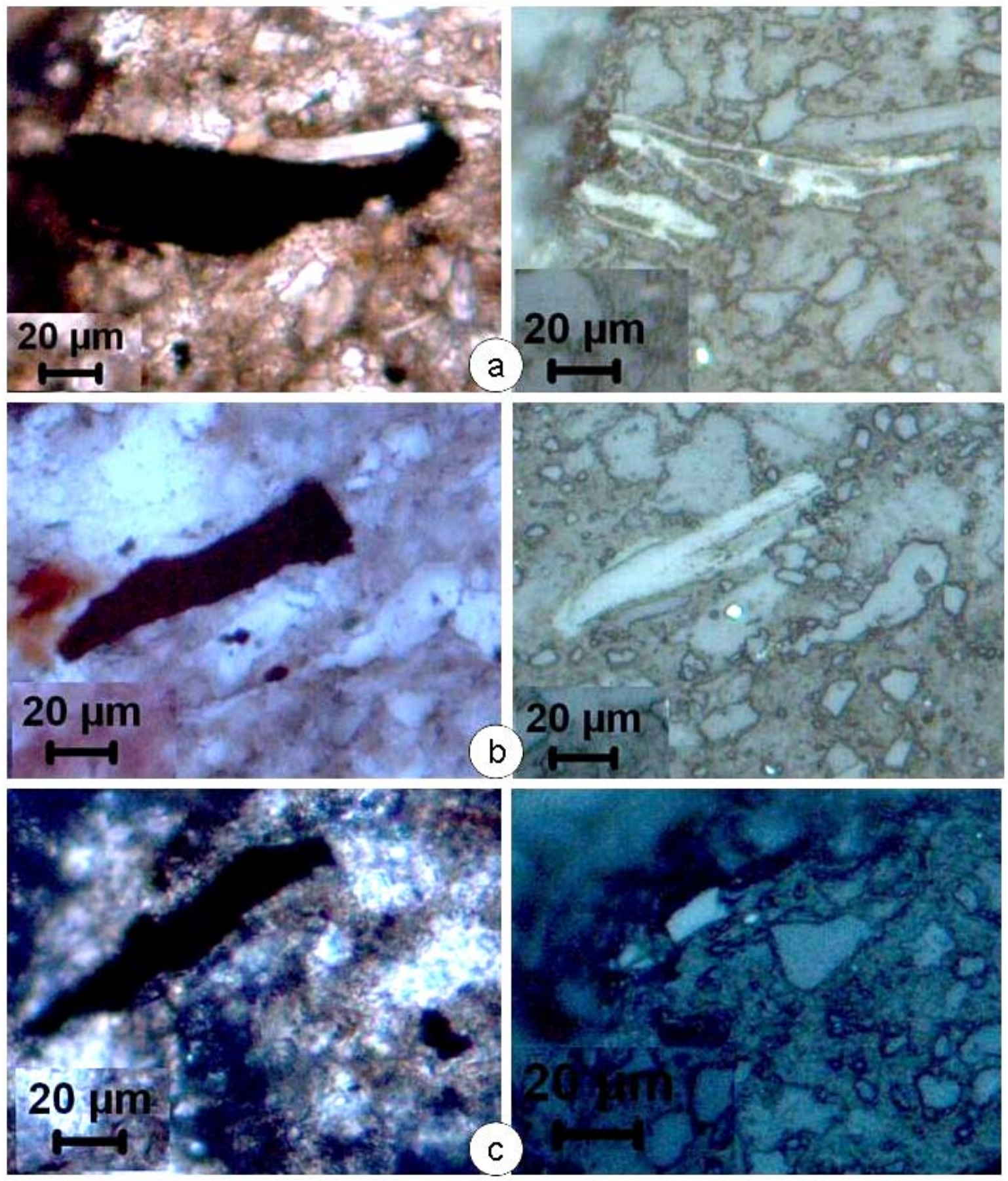

Figure 6: Micrographs of 3 black particles of organic matter in natural transmitted light (left side) and in reflected light (right side). a) semi-fusinite, b) first vitrinite sample, c) second vitrinite sample. 


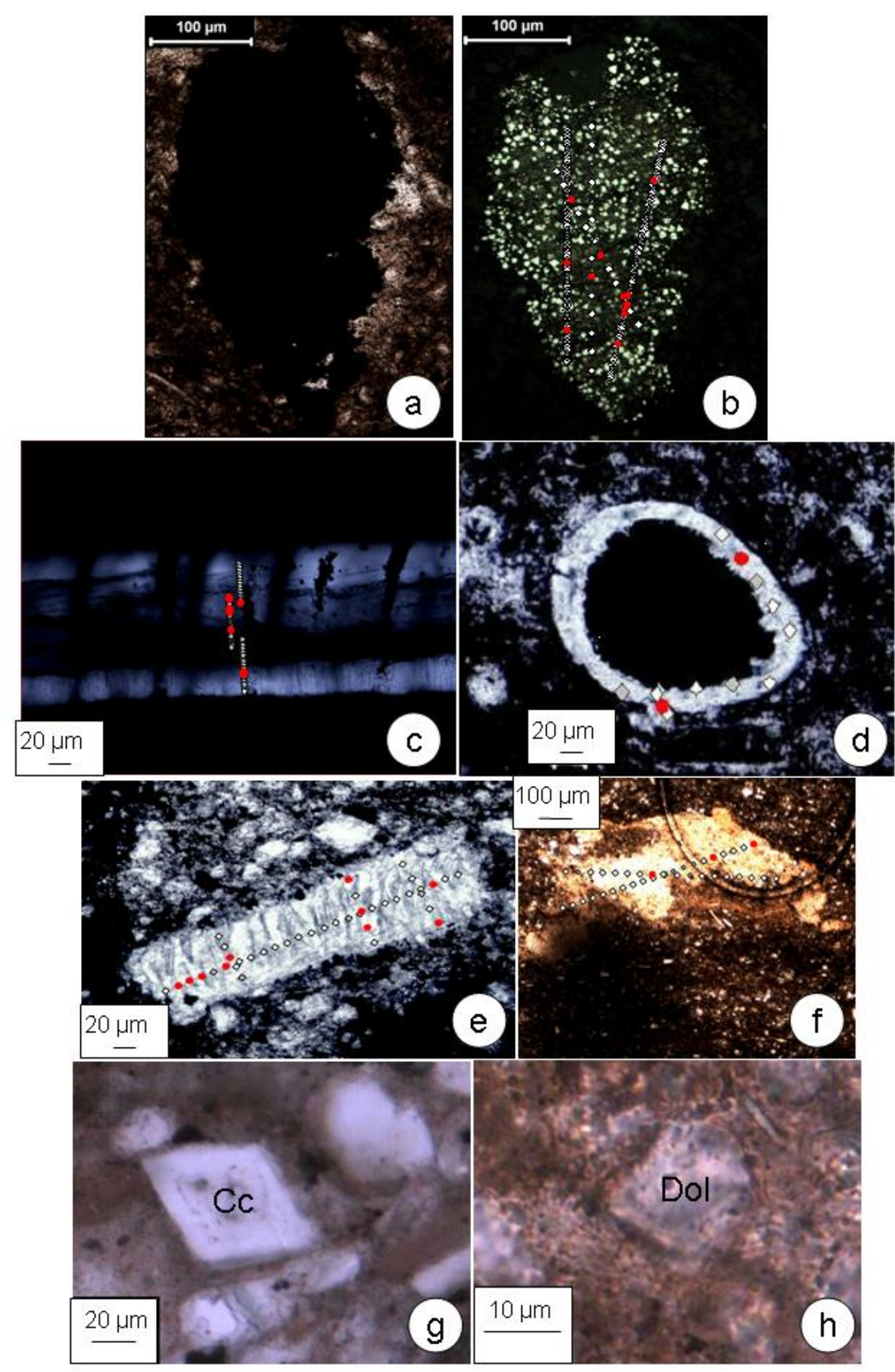

Figure 7: a-b: transmitted light and reflected light - a pyrite + organic matter zone - sample EST25687. c: transmitted light - cross-section of a terebratula shell formed by alternations of fibrous calcite (or aragonite) - sample EST12436. d - Transmitted light - unknown fossil EST 25687.e - Transmitted light - shell formed by fibrous calcite - EST25687.f Transmitted light - honey coloured phosphatic clast without structure - EST25687. g - 
Transmitted light - euhedral grain of calcite (Cc) - EST 25380. h - Transmitted light euhedral grain of dolomite (Dol) - EST 25380. 